\title{
A Brief Analysis of Color Symbols in Beloved from the Perspective of Conceptual Metaphor
}

\author{
Mengsi Yin \\ Col. Of Humanities and Law, North China Univ. Of Tech.,100144, Beijing, China. \\ 794619603@qq.com
}

Keywords: Beloved; Conceptual metaphor; Color symbol

\begin{abstract}
Toni Morrison is one of the most respected American writers and culture critics. She won the Pulitzer Prize and the American Book Award in 1988 for Beloved. She was awarded the Nobel Prize in Literature in 1993. The research on her works is endless. This thesis, which centered around the color symbols in Beloved, try to illustrate all color symbols from the perspective of conceptual metaphors and bring some more information and inspiration for readers.
\end{abstract}

\section{Introduction}

The English word "metaphor" actually originated from a Middle French word "metaphore" or Latin "metaphora". The root of the two words is the Greek "metapherein", with "meta" denoting "across" and "pherein" implying "carry". This word refers to transference from one thing to another as a whole word. This is the etymological explanation of "metaphor" form Merriam-Webster's $11^{\text {th }}$ Collegiate Dictionary.

Aristotle once said by far the greatest thing is to be a master of metaphor. It is the one thing that cannot be learned from others. According to Lakoff \& Johnsen's Metaphors We Live By, metaphor was defined as a mode of experiencing other things with a thing. Metaphor is pervasive in everyday life, not just in language but in thought and action. Our ordinary conceptual system, in terms of which we both think and act, is fundamentally metaphorical in nature[1]. The concepts that govern our thought are not just matters of the intellect. They also govern our everyday functioning, down to the most mundane details. Our concepts structure what we perceive, how we get around in the world, and how we relate to other people. Our conceptual system thus plays a central role in defining our everyday realities. Though conceptual metaphor is a conventionalized mapping between two different domains of experience, some metaphorical concepts seem to be universal, others are widespread, and some seem to be culture-specific. Amid these metaphoric concepts, color terms are widely used in different language genres in literal or metaphoric senses and may reflect cultural identities of the language users[2].

Beloved is a novel written by the American writer Toni Morrison. Set after the American Civil War, it is inspired by the story of an American slave, Margaret Garner, who escaped slavery in Kentucky by fleeing to Ohio. In the novel, the protagonist Sethe is also a slave who escapes slavery, running to Cincinnati, Ohio. After 28 days' freedom, a posse arrives to retrieve her and her children under the Fugitive Slave Act of 1850, which gave slave owners the right to pursue slaves across state borders. Sethe kills her two-year-old daughter rather than allow her to be recaptured and taken back to Sweet Home, the Kentucky plantation from which Sethe recently fled. A woman presumed to be her daughter, called Beloved,, returns years later to huant Sethe's home at 124 Bluestone Road, Cincinnati, Ohio.

\section{Color metaphors in Beloved}

As Lakoff and Johnson hold, metaphors are formed by our body, brain and worldly experience and can be understood only through them. Since human brains are almost identical in physical construction, there must be some similarities in human cerebral activities including metaphor conceptualization, no matter in which country he lives[3]. Color concepts are anchored in certain universals on human experience, and these universals can be identified[4]. There are many color 
concepts in Beloved, those colors can help construct atmosphere, portray characters, reveal themes, make clear author's attitude and construct plots.

\section{"Red" metaphors in Beloved.}

In western culture, red color symbolizes blood, violence, desire, passion and danger and is frequently associated with death and immortality. In this story, as for Beloved, she always appears with a beam of red light.

"Paul D tied his shoes together, hung them over his shoulder and followed her through the door straight into a pool of red and undulating light that locked him where he stood."

The beam of red light, which covered the house 124, is actually the ghost of Beloved. The red light drives two sons away and keeps company with Denver. It stands for the permanent injury of slavery which can not wipe out even after slaves achieve freedom. The red light also refers to Beloved's blood. Her death is the family's trauma lingering in the house 124 . Red is a passionate color, in the story, it may reflects the desire and possibility of living a new life. It's not only Beloved's desire, it's all colored people's pursuit and dream.

To Sethe, when school teacher and his nephews took over the Sweet Home, everything changed, even her eyes.

"Now the iron was back but the free, softened by hair, made him trust her enough to step inside her door smack into a pool of pulsing red light."

The so called "noble" school teacher is actually a monster. He and his nephews who took Sethe's milk, abused her and made a sycamore tree in her back. Under slave holders' violent oppression, Sethe lost the passion in her eyes instead of depression and emptiness.

"Enough nigger eyes for now. Little nigger-boy eyes open in sawdust; little nigger-girl eyes staring between the wet fingers that held her face so her head wouldn't fall off."

Three children's blood announced the end of their life. The blood scared the posse and saved the rest lives of the family. So the bloody red here stands for colored people's resistance and determination. It also symbolizes the bloody violence of slavery which force colored people to choose death rather than life.

"When she came back, Sethe was aiming a bloody nipple into the baby's mouth."

Beloved's death saved others' lives. Denver drank Sethe's milk which was mixed with Beloved's blood. To some extent, the bloody red is the redemption of life but it is over horrifying[5].

It's pretty tempting to say that the red heart represents love, passion, life-something like that. While, to Paul D, when he had sex with Beloved, he said "red heat" again and again. And we may infer that the red heart doesn't symbolize any positive meaning.

"Beloved." He said it, but she did not go... "Red heart. Red heart," over and over again. Softly and then so loud it woke Denver, then Paul D himself. "Red heart. Red heart. Red heart."

The red heart here is what Paul D lost. It refers to his manhood and dignity. He lost his manhood when he was captured and sold to be a slave. The physical and mental harm which force him to forget who he is and what he lost.

\section{"Lavender" and "Pink" metaphors in Beloved.}

Baby Suggs said, "Bring a little lavender in, if you got any. Pink, if you not". Lavender, which is actually the light purple, symbolizes femininity, nobility, grace and elegance. For Baby Suggs those things are what she longed for all her life. She wanted to be treated like an ordinary female woman rather than a colored slave. She tried hard to influence other colored people to find their dignity and grace back together. Pink, which symbolizes love, romance, caring, tenderness, acceptance and calm. For Baby Suggs, the color pink is as good as lavender. And they can convey the same perception. For Sethe, pink is the color of her daughter's gravestone. And it is the last color she can remember. It reminds her the fact that she killed her daughter by herself. Hence, pink symbolizes mother's deep love and tenderness to her children as well as the end of life.

"Gray", "White" and "Black" metaphors in Beloved.

Both gray and white symbolize old age, sadness, boring, lifeless, simplicity, sterility, death and clinical.

"Sethe, their mother; and their little sister, Denver, all by themselves in the gray and white house 


\section{on Bluestone Road."}

"Out of the dimness of the room in which they sat, a white staircase climbed toward the blue-and-white wallpaper of the second floor."

"The luminous white of the railing and steps kept him glancing toward it.

"He looked quickly up the lighting-white stairs behind him."

The house 124, a gray and white house. Through the color gray, we can know that the house is lifeless, stark and gloomy. The color white associated with death and horror. The house is a haunted house which full of spite and venom. The house is the setting of the story, so the color of 124 is the main color of the story. We can infer the cold atmosphere, chilling plots as well as the tragic destiny of characters.

In western legend, Death is often shown in human skeleton, wearing black gown with a scythe in his hands. "Black death" is a deadly plague widespread during Middle Ages when it led to the decrease of the population to nearly half in Western Europe. "Wear black for someone" and "black job" are closely related to death. "Black Friday" is the Friday before Easter on which Jesus Christ had arrived in Jerusalem, eaten the last supper with his twelve disciples and then suffered from crucifixion for the sins of the common people. Based on this cultural background, "black Friday" is widely used to refer to a day darkened by catastrophe or misfortune in English speaking countries[6]. In this story, the most important and striking color is black. That is because the colored people are the main characters. The root of all the miserable facts and sins is the superiority of white, black as the inferior and suffering level has to accept unfair treatment. Black is not only their skin color, but also their destiny[7]. While the author Toni Morrison may wants to expose the sin of the white and the darkness of slavery to readers. It may appeals or wakens people's conscience and morality.

\section{"Green", "Yellow" and "Orange" metaphors in Beloved.}

Green symbolizes nature, healthy, good luck, renewal and vigor.

"Veiled and protected by the live green walls, she felt ripe and clear, and salvation was as easy as a wish."

"Bent low, Denver could crawl into this room, and once there she could stand all the way up in emerald light."

This is Denver's emerald secret house, which is animate and safe, was constructed by green plants. Denver enjoys the green light in the house. That is because the green light means hope and security which can take her away from loneliness and miserable life.

"Yet it was to the Clearing that Sethe determined to go-to pay tribute to Halle. Before the light changed, while it was still the green blessed place she remembered: misty with plant steam and the decay of berries."

Clearing, which was covered by green, is a holy green place for all colored people. It is not only for Baby Suggs or Sethe. The color green of "Clearing" refers to the power of nature, freedom which the colored people longed for, courage of living a new life. For Sethe, the green wood which she crosses through gives her hope and vigor and helps her escape from Sweet Home. She also hope this vigor can help her escape from slavery.

Yellow is a color of joy, happiness, optimism, hope as well as illness.

"Paul D could see just the beginning of the paper; discreet flecks of yellow sprinkled among a blizzard of snowdrops all backed by blue."

The house 124 is a gray and white house. But Baby Suggs prefers to furnish her house with a little color yellow which can make the house lively and energetic. She wants to use some color yellow to bury the gloomy and mirthless atmosphere.It's a sign of hope and it also symbolizes a peaceful death of Baby Suggs and Mrs. Garner[8] .

"At least it seemed so. A few yellow flowers on the table, some myrtle tied around the handle of the flatiron holding the door open for a breeze calmed her.

"As though a handful of myrtle stuck in the handle of a pressing iron propped against the door in a white woman's kitchen could make it hers."

After school teacher took over the Sweet Home, Sethe extremely wants to get a peaceful and safe 
life. The color yellow also refers to her pursuit of an identity.

Orange is a sign of energy, enthusiasm, warmth and vibrant.

"It took three days for Beloved to notice the orange patches in the darkness of the quilt."

Baby Suggs's quilt stands for a positive attitude of life which was mixed with some other colors. And Beloved was only attracted by the color orange when she was sleeping in the bed. The color orange here refers to the tender part of her personality. What's more, the color orange also stands for every characters' hope. Now matter how misery life is, all of them still have a bright filed in their heart. They still expected that they may finally have a better life. The color orange is a beam of hopeful light which lighten colored people's road.

\section{Conclusion}

Through the above analysis, we can figure out those color metaphors more clearly. The major theme of this novel is slavery. Beloved shows the process of black women's subjective consciousness from sleepy to awakening, from spontaneous to conscious[9]. However, different color stands for different conceptual meaning. All in all, red symbolizes the destruction of identity and the trauma of slavery. White and gray are the color of the past which convey the chilling atmosphere of colored people's miserable life. Orange and yellow indicate the hope of recovering from slavery. Lavender and pink are the symbols of pursuing female identity and a dignity life. Colors have their own extended sense in this story which are transferred by their conceptual meanings. If we can dig the deep meaning out, we can understand this novel better.

Note: all quotations are taken from Beloved, 外语教学与研究出版社, 2006.

\section{References}

[1] George Lakoff and Mark Johnsen. Metaphors We Live by[M].The University of Chicago Press, 2003.

[2] Mohammad Aliakbari, A Corpus analysis of color-term conceptual metaphors in Persian proverbs[J]. Procedia - Social and Behavioral Sciences, 2013.

[3] George Lakoff, Cognitive Linguistics: What It Means and Where It Is Going[J], Journal of Foreign Languages, 2005.

[4] Jin Xing. A Contrastive Study of the Metaphorical Use of English and Chinese Basic Color Terms-From the Theoretical Perspective of Conceptual Metaphor[D], Ji Lin University, 2012.

[5]Luo Yi.The fate of the characters - an analysis of the metaphorical meaning of red in Beloved[J]. The Writing Theory Research, 2012.

[6] Liu Wenting. A contrastive analysis of the metaphorical meanings of colors words in English and Chinese[J]. Journal of Language and Literature, 2014.

[7] Huang Wenjuan, Tao Jiajun. Unbearable pain in life-The research of intergenerational truma of the black people in Beloved[J].Foreign Literature, 2011.

[8] Xiong Lei. A Contrastive Analysis of Conceptual metaphor Cognition and Culture of Color words "Yellow", "Green" and "Red" in English and Chinese[J]. Journal of He Nan University, 2013.

[9] Yang Wen. On feminism in Beloved[J]. Times Literary, 2011. 